\title{
The production characteristics of volatile organic compounds and their relation to growth status of Staphylococcus aureus in milk environment
}

\author{
J. Chen, ${ }^{1}$ J. N. Tang, ${ }^{1,2}$ K. L. Hu, Y. Y. Zhao, and C. Tang \\ College of Life Science and Technology, Southwest University for Nationalities (Southwest Minzu University), Chengdu, China, 610041
}

\begin{abstract}
In our previous research, 3-methyl-butanal and 3-methyl-butanoic acid were identified as representative and specific volatile organic compounds released by Staphylococcus aureus in broth. In this study, we explored the production of the 2 volatiles and their correlation to Staph. aureus growth in milk under different conditions. We found significant correlations between the production of 3-methyl-butanoic acid and cell counts of 5 Staph. aureus strains in sterile milk, and there were no obvious differences for its production among 5 tested strains. The intensities of the 2 volatiles were similar and positively correlated with bacterial counts in cultures at $25^{\circ} \mathrm{C}$ and $37^{\circ} \mathrm{C}$ despite delayed production of volatiles at $25^{\circ} \mathrm{C}$; however, neither compound could be detected at $4^{\circ} \mathrm{C}$. The production of 3-methyl-butanoic acid was strongly correlated with growth of Staph. aureus mixed with Streptococcus agalactiae, Escherichia coli O157:H7, and Shigella flexneri, whereas correlations for 3-methyl-butanal were not statistically significant. Compared with the monoculture of Staph. aureus, in mixed cultures, production of 3-methyl-butanal was decreased and that of 3-methylbutanoic acid was comparatively higher. In pasteurized and raw milks, production of 3-methyl-butanoic acid was correlated with growth of Staph. aureus, and 3-methyl-butanoic acid could be detected when Staph. aureus populations reached $10^{6}$ to $10^{7} \mathrm{cfu} / \mathrm{mL}$ in pasteurized milk and $10^{5}$ to $10^{6} \mathrm{cfu} / \mathrm{mL}$ in raw milk; the correlations for 3-methyl-butanal were not statistically significant. Our results suggest that 3-methyl-butanoic acid is a more suitable marker for high counts of Staph. aureus in milk, whereas 3-methyl-butanal is a transient metabolite and easily depressed by environmental factors.
\end{abstract}

Received August 15, 2017.

Accepted December 2, 2017.

${ }^{1}$ These authors contributed equally to this work.

${ }^{2}$ Corresponding author: junneytang@aliyun.com
Key words: Staphylococcus aureus, milk, bacterial volatile compounds, growth, correlation

\section{INTRODUCTION}

Among etiological agents in bovine mastitis, Staphylococcus aureus is the most prevalent pathogen. Staphylococcus aureus mastitis is a serious problem in the dairy industry, and infected bovines may contaminate individual milk and bulk tank milk. In China, 894 bulk tank milk samples collected from dairy herds were examined for the presence of mastitis pathogens, and Staph. aureus was detected in $50.1 \%$ of all bulk tank milk samples (Bi et al., 2016). Similarly, the prevalence of Staph. aureus in bulk tank milk samples from Ohio dairy herds was estimated to be 48 to $69 \%$ (da Costa et al., 2016). In the study of Gücükoğlu et al. (2012), Staph. aureus was detected in 45 of 60 (75\%) raw milk samples, and the level of Staph. aureus contamination was $>10^{5}$ to $10^{6} \mathrm{cfu} / \mathrm{mL}$ in 17 of 60 raw milk samples obtained from Samsun province, Turkey. These findings indicate that a high percentage of raw milk samples are contaminated with high cell counts of Staph. aureus. Dairy products from raw milk contaminated with Staph. aureus constitute a potential risk to public health. Proper pasteurization could inactivate all Staph. aureus; however, failure of pasteurization or postprocessing contamination could lead to the presence of viable Staph. aureus in milk products after pasteurization. For example, Akindolire et al. (2015) measured pasteurized milk samples from retail outlets of the Northwest province, South Africa, and showed that 10 of 75 pasteurized milk samples were positive for Staph. aureus. In the investigation of Vahedi et al. (2013), contamination with Staph. aureus was observed in 2 of 100 pasteurized milk samples randomly from supermarkets in Sari, Iran. Mirzaei et al. (2011) examined 200 milk and dairy products in Sarab, Iran, and indicated that 4 pasteurized milk samples were contaminated by coagulase-positive Staph. aureus. Thus, milk is a common source of food-borne disease, and detection of Staph. aureus in milk is very important. 
In raw milk and milk products, Staph. aureus could be detected by using classical microbiological methods and PCR techniques. However, bacteriological culture is time and labor consuming, and it is difficult to perform PCR directly on milk because it is a complex food matrix. Therefore, there is an urgent need to implement rapid and accurate detection technology to control contamination and the spread of Staph. aureus in raw milk and milk products.

Microbial volatile organic compounds are interlinked to microbial metabolism and bacterial populations localized on the surfaces of biological samples. Hettinga et al. (2008) suggested a comparable method for mastitis pathogen identification based on volatile metabolites analysis in raw milk, and indicated that Staph. aureus produced a different pattern of volatile metabolites from other mastitis pathogens. Their studies reported that Staph. aureus produced high amounts of 3-methyl-butanal, especially, and Staph. aureus could be differentiated from other mastitis pathogens on the basis of the production of branched fatty acids, such as 2-methyl butyrate. A later study, Hettinga et al. (2009a), showed that 2- or 3-methyl-butanal and 2- or 3 -methyl butyrate formed in inoculated milk were similar to the volatile metabolites formed in milk from cows with mastitis. This showed the possibility of detecting Staph. aureus in milk based on its volatile metabolites.

Volatile metabolites of Staph. aureus in tryptic soy broth were previously analyzed by Filipiak et al. (2012) and showed that Staph. aureus released specifically 3-methyl-butanal (at high concentration) and 3-methyl-butanoic acid (at moderate concentration). Bos et al. (2013) found that 3-methyl-butanoic acid and 2-methyl-butanal were biological markers for the presence of Staph. aureus. Tait et al. (2014) identified that Staph. aureus specifically produced 3 -methy-butanoic acid in 3 media (brain heart infusion, tryptic soy broth, $1 \%$ glucose enteric fermentation base broth) and 3-methylbutanal in $1 \%$ glucose enteric fermentation base broth. In our previous study, we also presented that 3-methylbutanoic acid and 3-methyl-butanal were volatile biomarkers for Staph. aureus in tryptic soy broth (Chen et al., 2017).

3-Methyl-butanal and 3-methyl-butanoic acid are regarded as representative and specific volatiles released by Staph. aureus; however, the production profile of these volatiles and the relation to Staph. aureus growth status have not been reported in milk. In this study, we investigated the production of volatiles and growth of several Staph. aureus strains in pure culture and mixtures of Staph. aureus with other pathogens at different cultivation temperatures in sterile milk. This explora- tion should support the use of representative volatiles as stable markers to detect Staph. aureus in milk.

\section{MATERIALS AND METHODS}

\section{Strains and Cultures}

The strains Staphylococcus aureus ATCC 6538, Streptococcus agalactiae CICC 10465, Escherichia coli O157:H7 CICC 21530, Salmonella enterica serovar Enteritidis CICC 21482, and Shigella flexneri CGMCC 1.1868 were used. The CICC strains were from the China Center of Industrial Culture Collection (Beijing, China); and CGMCC strains were from China General Microbiological Culture Collection Center (Beijing, China).

Isolate strains from were also acquired from hospital patients with food poisoning in Chongqing, China, designated Staph. aureus $\mathrm{H} 3, \mathrm{H} 4, \mathrm{H} 5$, and H8. For each bacterium, a fresh bacterial culture was prepared in trypticase soy broth (TSB; Qing Dao Hope BioTechnology Ltd. Corp., QingDao City, China) for $14 \mathrm{~h}$ at $37^{\circ} \mathrm{C}$ with agitation at $150 \mathrm{rpm}$.

\section{Detection of Growth and Volatile Compounds of Staph. aureus in Sterile Milk}

Ultra-high-temperature milk was purchased from a local supermarket and used as sterile milk. A fresh bacterial culture of each Staph. aureus was inoculated into $1 \mathrm{~L}$ of sterile milk in a flask, and the initial inoculation level amounted to 100 to $200 \mathrm{cfu} / \mathrm{mL}$. The incubation conditions were $37^{\circ} \mathrm{C}$ with agitation at $150 \mathrm{rpm}$ for $24 \mathrm{~h}$. Blank (uninoculated) sterile milks were used as controls. The growth of Staph. aureus was determined by enumerating bacterial cells at 2 -h intervals. A $1-\mathrm{mL}$ volume of sample culture was collected and serially diluted in saline. Appropriate dilutions were spread on Baird-Parker plates (Qing Dao Hope Bio-Technology Limited Corp.), and 3 replicated samples were obtained at each sampling time. The volatiles were detected by headspace-solid-phase microextraction with GC-MS analysis at 2-h intervals, and the detection method referred to our previous publication (Chen et al., 2017). Briefly, the 5-mL sample was transferred into a $20-\mathrm{mL}$ amber screw-cap vial with addition of $2 \mathrm{~g}$ of $\mathrm{NaCl}$. The solid-phase microextraction fiber was $50 / 30 \mu \mathrm{m}$ divinylbenzene/carboxen/polydimethylsiloxane. All steps, including preheating $\left(80^{\circ} \mathrm{C}, 10 \mathrm{~min}\right)$, extraction $\left(80^{\circ} \mathrm{C}, 30 \mathrm{~min}\right)$, desorption $\left(230^{\circ} \mathrm{C}, 2 \mathrm{~min}\right)$, analyzing, and cleaning $\left(250^{\circ} \mathrm{C}, 10 \mathrm{~min}\right)$, were conducted automatically using a Triplus auto-sampler (Thermo Fisher 
Scientific, Waltham, MA). The GC-MS analysis was performed using a Thermo Trace GC ultra DSQ II (Thermo Fisher Scientific). Volatile compounds were separated using HP-5MS column $(30 \mathrm{~m} \times 0.25 \mathrm{~mm}$ $\times 0.25 \mu \mathrm{m})$. Three replicate samples were obtained at each sampling time.

\section{Detection of Growth and Volatiles of Staph. aureus at Different Temperatures in Sterile Milk}

Fresh bacterial culture of Staph. aureus 6538 was inoculated into $1 \mathrm{~L}$ of sterile milk in a flask at an initial inoculation level of 100 to $200 \mathrm{cfu} / \mathrm{mL}$. The incubation conditions were $37^{\circ} \mathrm{C}$ with agitation at $150 \mathrm{rpm}$ for 24 $\mathrm{h} ; 25^{\circ} \mathrm{C}$ with agitation at $150 \mathrm{rpm}$ for $36 \mathrm{~h}$; or $4^{\circ} \mathrm{C}$ with static cultivation for $22 \mathrm{~d}$. Samples of bacterial culture were collected every 2 or $3 \mathrm{~h}$ for $37^{\circ} \mathrm{C}$ and $25^{\circ} \mathrm{C}$ cultures and every $2 \mathrm{~d}$ for $4^{\circ} \mathrm{C}$ cultures. The subsequent steps were the same as described above.

\section{Detection of Growth and Volatiles of Staph. aureus in Mixed Cultures in Sterile Milk}

The combinations of Staph. aureus and Strep. agalactiae, Staph. aureus and E. coli O157:H7, Staph. aureus and Salmonella Enteritidis, and Staph. aureus and S. flexneri were used as mixed cultures. Fresh bacterial cultures of these target pathogens were inoculated into $1 \mathrm{~L}$ of sterile milk in a flask at initial inoculation levels of 100 to $200 \mathrm{cfu} / \mathrm{mL}$. The incubation condition was $37^{\circ} \mathrm{C}$ with agitation at $150 \mathrm{rpm}$ for $24 \mathrm{~h}$. Blank sterile milks were used as controls. The following steps were the same as described above.

\section{Detection of Growth and Volatiles of Staph. aureus in Pasteurized and Raw Milks}

Pasteurized milk samples were purchased from a supermarket in the Wuhou district of Chengdu city, and individual raw milk samples were collected from dairy herds in Shuangliu district of Chengdu city, Sichuan province, China. The total bacterial counts were determined to be 1 to $3 \times 10^{6} \mathrm{cfu} / \mathrm{mL}$ for raw milk and 5 to $9 \times 10^{3} \mathrm{cfu} / \mathrm{mL}$ for pasteurized milk. Among the total bacteria, approximately 1 to $2 \times 10^{4} \mathrm{cfu} /$ $\mathrm{mL}$ were recognized to be Staph. aureus in raw milk samples, whereas Staph. aureus was not found in pasteurized milk samples. At the same time, fresh bacterial culture of Staph. aureus 6538 was inoculated into $1 \mathrm{~L}$ of pasteurized milk or raw milk in a flask at an initial inoculation level of 100 to $200 \mathrm{cfu} / \mathrm{mL}$. The incubation condition was $37^{\circ} \mathrm{C}$ with agitation at $150 \mathrm{rpm}$ for $24 \mathrm{~h}$. The growth and volatile production of Staph. aureus were determined at 2 -h intervals. Three pasteurized milk samples and 3 raw milk samples were examined. The bacterial counting and the volatile detecting were conducted according to the methods described above.

\section{Data Analysis}

We investigated temporal production of volatiles and growth levels of Staph. aureus in samples, and statistical analysis was conducted using OriginPro 7.5 (version 7.5776, OriginLab, Northampton, MA). The correlations between measured volatile compound concentrations and bacterial counts were calculated by Spearman correlation coefficient, using SPSS Statistics 17.0 (SPSS Inc./IBM Corp., Chicago, IL).

\section{RESULTS}

\section{Production of Volatiles and Relation to Growth of Different Staph. aureus Strains}

As can be seen in the time-dependent production profile of the volatiles in Figure 1A, the signal intensity of 3-methyl-butanal from Staph. aureus 6538 and H4 increased and then decreased slowly, whereas levels of 3-methyl-butanal in Staph. aureus H3, H5, and H8 increased up to the maximum followed by a sharp decrease to zero. It is important to note that, in Figure 1, the signal intensity of 3-methyl-butanal from the reference strain $\left(\times 10^{7}\right.$ on $y$-axis $)$ was about 10 -fold higher than that from isolate strains $\left(\times 10^{6}\right.$ for $y$-axis $)$. As shown in Table 1, correlations between 3-methyl-butanal intensities and bacterial counts from Staph. aureus $6538(P<$ $0.01)$ and $\mathrm{H} 4(P<0.05)$ were significant, whereas those between 3-methyl-butanal and counts of Staph. aureus $\mathrm{H} 3, \mathrm{H} 5$, and $\mathrm{H} 8$ were not significant. In addition, signal intensities of 3-methyl-butanoic acid increased from 8 to $10 \mathrm{~h}$ and then increased continuously or remained stable; there were no obvious differences in 3-methylbutanoic acid between the reference strain and isolate strains (Figure 1A). As shown in Table 1, correlations between 3-methyl-butanoic acid intensities and bacterial counts from 5 target Staph. aureus were all significant $(P<0.01)$.

\section{Production of Volatiles and Growth of Staph. aureus at Different Temperatures}

Neither 3-methyl-butanal nor 3-methyl-butanoic acid was detectable until 18 to $20 \mathrm{~h}$ at $25^{\circ} \mathrm{C}$ or 6 to $8 \mathrm{~h}$ at $37^{\circ} \mathrm{C}$ (Figure $1 \mathrm{~B}$ and $1 \mathrm{C}$ ), indicating that production of volatiles from Staph. aureus was delayed at $25^{\circ} \mathrm{C}$ because of the slower growth of Staph. aureus compared 


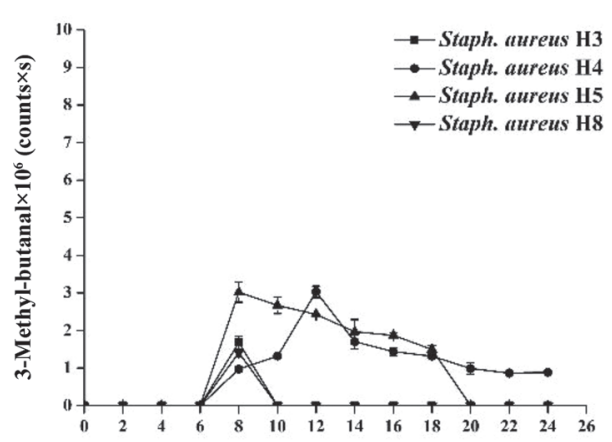

A
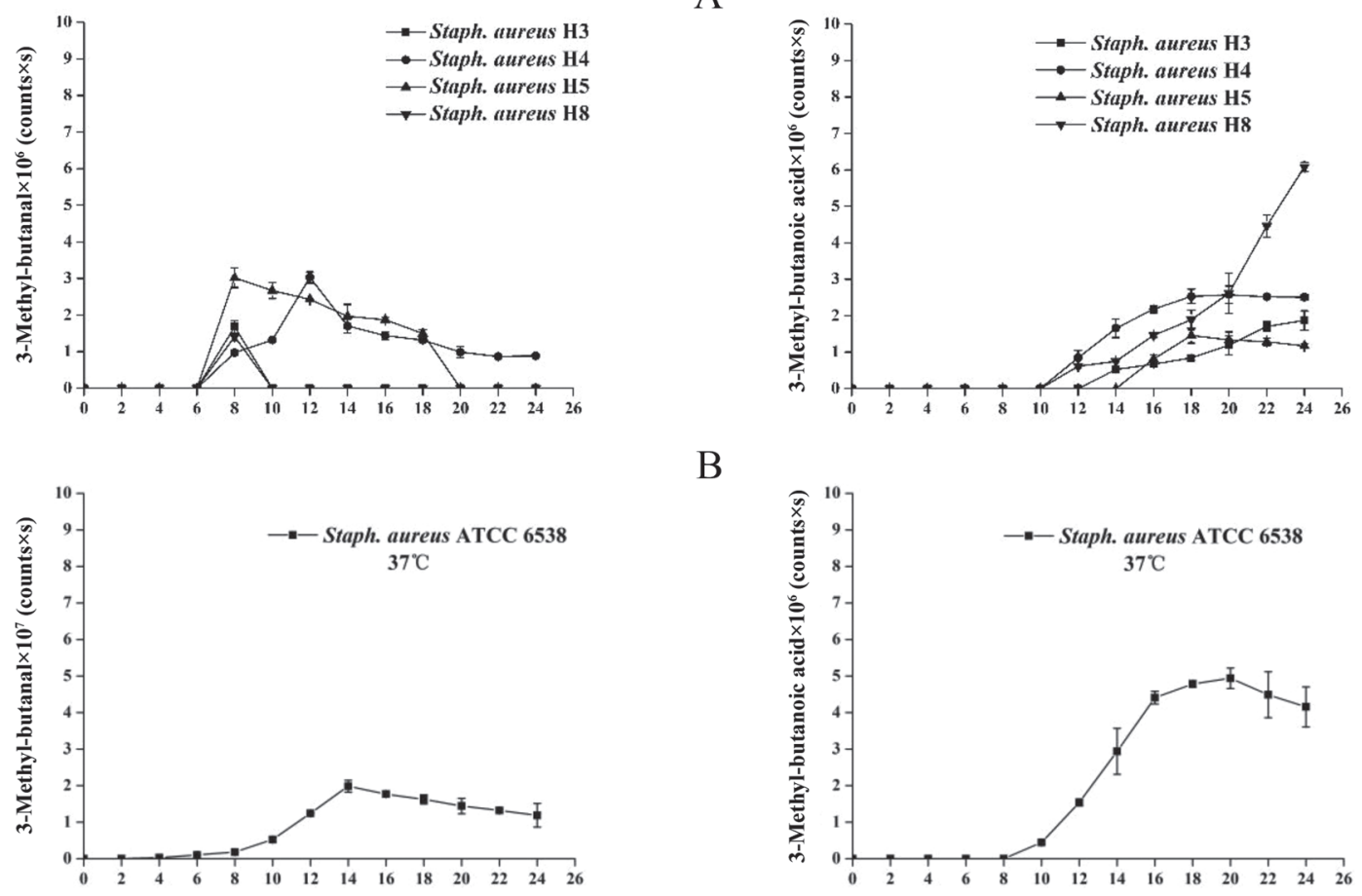

B
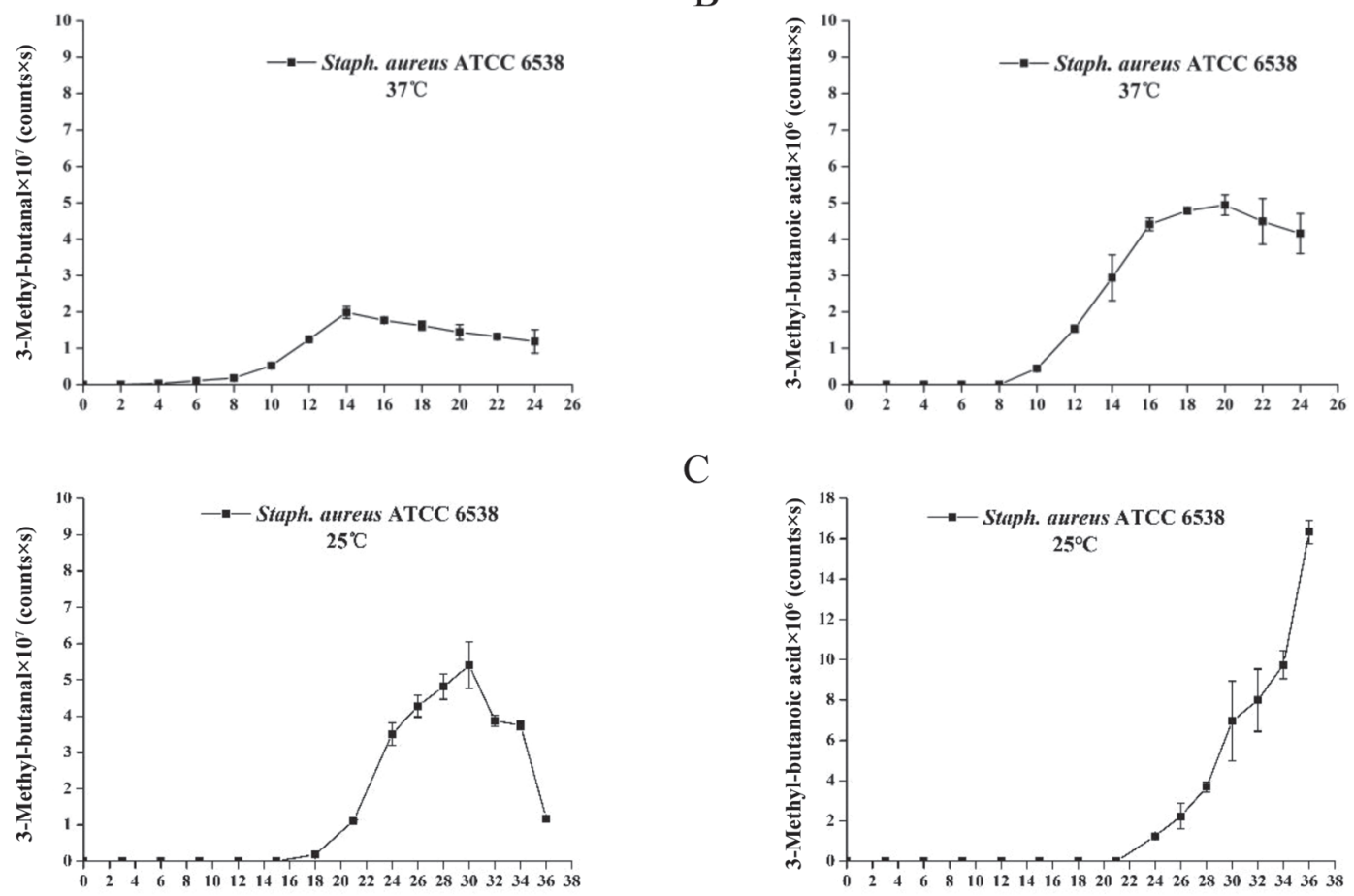

$\mathrm{C}$

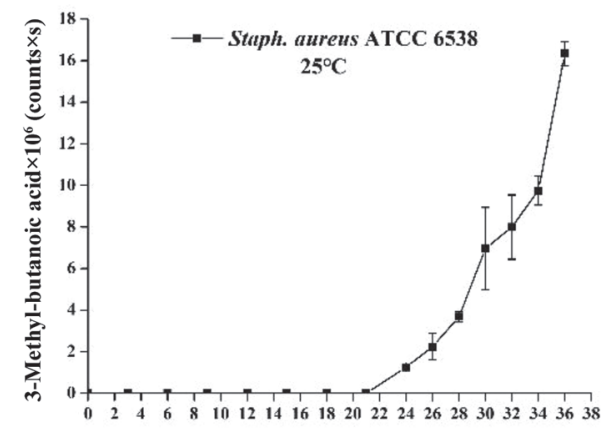

$\mathrm{D}$
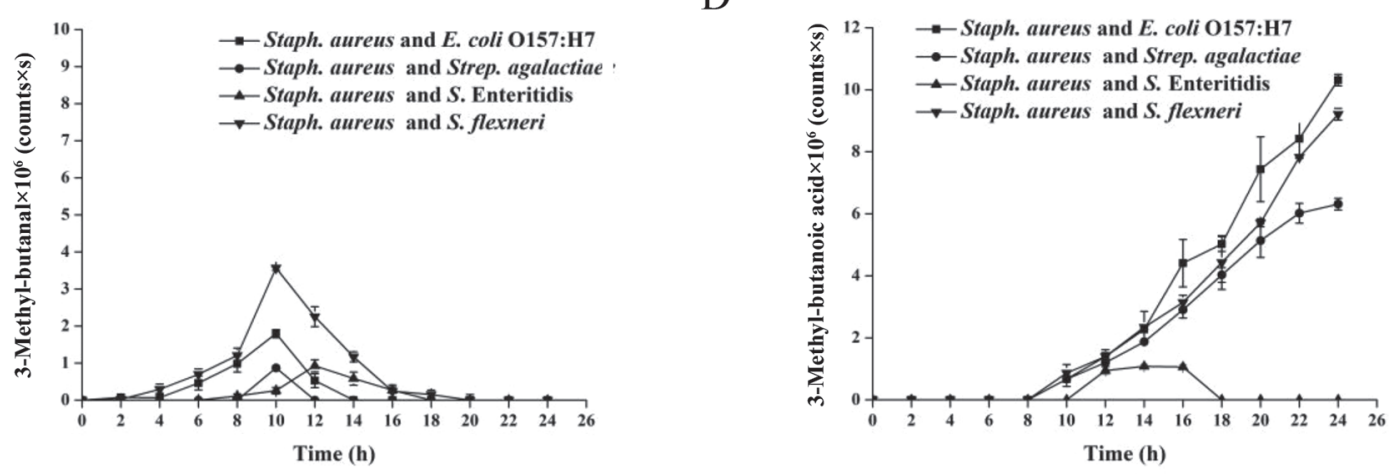

Figure 1. Time-dependent production of 3-methyl-butanal and 3-methyl-butanoic acid for Staphylococcus aureus isolates (hospital strains, $\mathrm{H} 3, \mathrm{H} 4, \mathrm{H} 5$, and H8) in sterile milk (A), for Staph. aureus ATCC 6538 at $37^{\circ} \mathrm{C}$ in sterile milk (B), for Staph. aureus ATCC 6538 at $25^{\circ} \mathrm{C}$ in sterile milk, and (D) for Staph. aureus ATCC 6538 mixed with other pathogens (Escherichia coli, Streptococcus agalactiae, Salmonella Enteritidis, or Shigella flexneri) in sterile milk. Note that the y-axis scale for production of 3-methyl-butanal in pure cultures of Staph. aureus ATCC 6538 is $\times 10^{7}$ counts/s, whereas that for other strains and mixed cultures is $\times 10^{6}$ counts/s. Error bars are SD. 

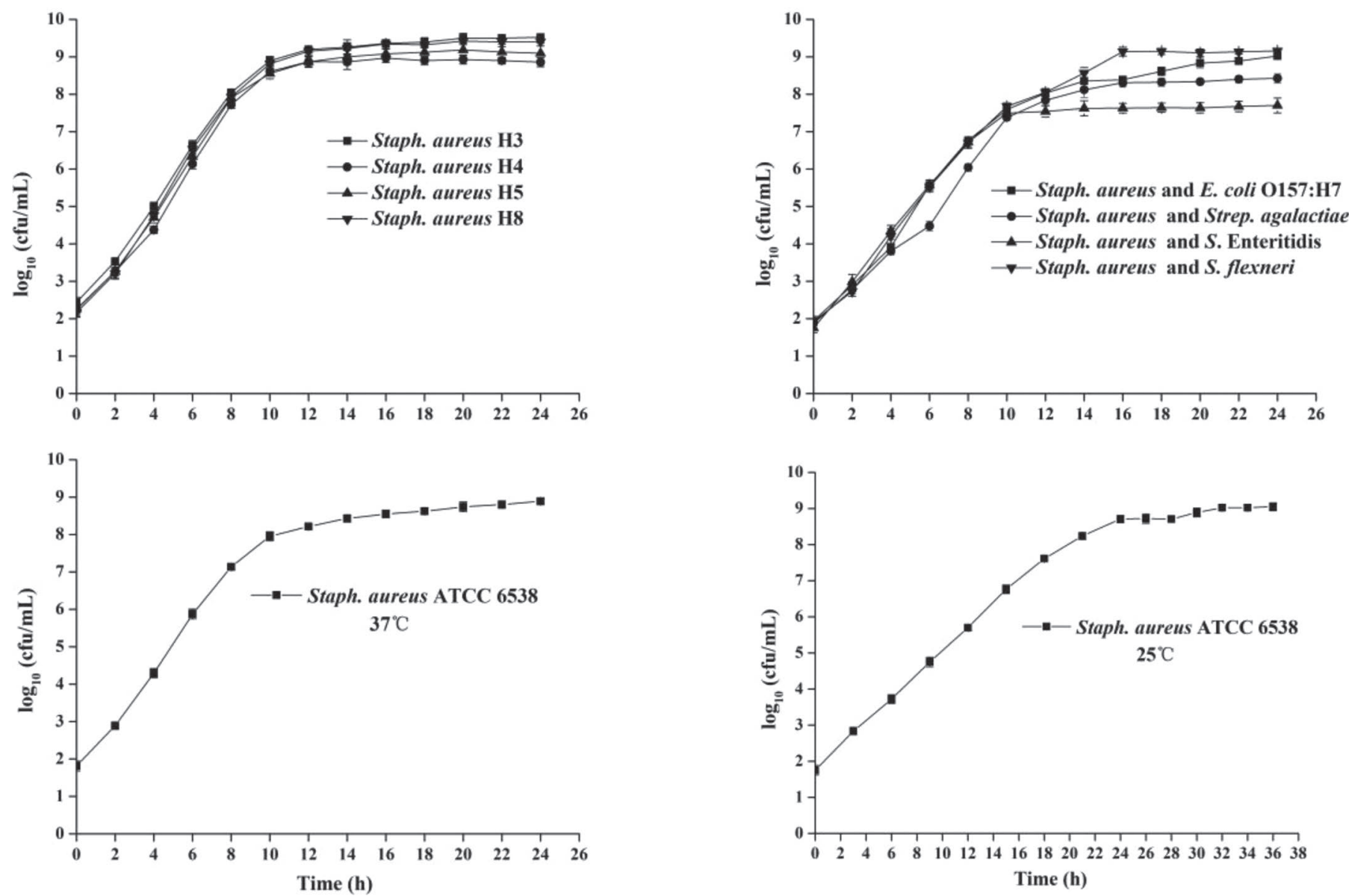

Figure 2. Growth curves of different strains of Staphylococcus aureus, mixed cultures (with Escherichia coli, Streptococcus agalactiae, Salmonella Enteritidis, or Shigella flexneri), and of Staph. aureus ATCC 6538 at 25 and $37^{\circ}$ C in sterile milk. Error bars are SD.

with that at $37^{\circ} \mathrm{C}$ (Figure 2). We did not find dramatic differences in levels of the 2 volatiles produced between $25^{\circ} \mathrm{C}$ and $37^{\circ} \mathrm{C}$. Furthermore, at $37^{\circ} \mathrm{C}$ and $25^{\circ} \mathrm{C}$, correlations between signal intensities of the 2 volatiles and bacterial counts of Staph. aureus were significant $(P<$ 0.01; Table 2). However, at $4^{\circ} \mathrm{C}, 3$-methyl-butanal and 3-methyl-butanoic acid could not be detected during the 22-d cultivation. The bacterial count of Staph. aureus increased from 100 to $200 \mathrm{cfu} / \mathrm{mL}$ to $2 \times 10^{3}$ to 3

Table 1. Correlation coefficients between bacterial counts and signal intensities of the volatile compounds 3-methyl-butanal and 3-methylbutanoic acid produced from 5 Staphylococcus aureus cultures

\begin{tabular}{lcc}
\hline Strain & 3-Methyl-butanal & 3-Methyl-butanoic acid \\
\hline Staph. aureus 6538 & $0.799^{* *}$ & $0.893^{* *}$ \\
Staph. aureus $\mathrm{H} 3$ & -0.154 & $0.914^{* *}$ \\
Staph. aureus $\mathrm{H} 4$ & $0.708^{* *}$ & $0.852^{* *}$ \\
Staph. aureus $\mathrm{H} 5$ & 0.084 & $0.871^{* *}$ \\
Staph. aureus $\mathrm{H} 8$ & -0.154 & $0.933^{* *}$ \\
\hline$* * P<0.01$.
\end{tabular}

$\times 10^{3} \mathrm{cfu} / \mathrm{mL}$ after $22 \mathrm{~d}$, and the metabolism of Staph. aureus was strongly inhibited at $4^{\circ} \mathrm{C}$.

\section{Production of Volatiles and Growth of Staph. aureus in Different Mixed Cultures}

The signal of 3-methyl-butanal from mixed cultures increased to a maximum and then decreased quickly to zero (Figure 1D). Correspondingly, in mixed cultures of

Table 2. Correlation coefficients between bacterial counts and signal intensities of the volatile compounds 3-methyl-butanal and 3-methylbutanoic acid produced from Staphylococcus aureus cultures under different temperatures

\begin{tabular}{lcc}
\hline Temperature $\left({ }^{\circ} \mathrm{C}\right)$ & 3-Methyl-butanal & 3-Methyl-butanoic acid \\
\hline 37 & $0.779^{* *}$ & $0.893^{* *}$ \\
25 & $0.813^{* *}$ & $0.910^{* *}$ \\
4 & -1 & - \\
\hline${ }^{1}$ Not detected. & & \\
$* * P<0.01$. & &
\end{tabular}


Table 3. Correlation coefficients between bacterial counts and signal intensities of the volatile compounds 3-methyl-butanal and 3-methyl-butanoic acid produced from mixed cultures

\begin{tabular}{lcc}
\hline Mixed culture & 3-Methyl-butanal & 3-Methyl-butanoic acid \\
\hline Staphylococcus aureus and Escherichia coli O157:H7 & -0.502 & $0.972^{* *}$ \\
Staph. aureus and Streptococcus agalactiae & -0.221 & $0.952^{* *}$ \\
Staph. aureus and Salmonella Enteritidis & 0.038 & 0.152 \\
Staph. aureus and Shigella flexneri & -0.215 & $0.927^{* *}$ \\
\hline$* * P<0.01$ &
\end{tabular}

Staph. aureus with Strep. agalactiae, Salmonella Enteritidis, E. coli O157:H7, or S. flexneri, correlations between 3-methyl-butanal intensities and bacterial counts of Staph. aureus were not significant (Table 3). On the other hand, production of 3 -methyl-butanoic acid in mixed cultures increased continuously throughout the period, except that it was heavily suppressed in the mixed culture with Salmonella Enteritidis. In mixed cultures, correlations between 3-methyl-butanoic acid intensities and bacterial counts of Staph. aureus were significant $(P<0.01)$ except for that of Staph. aureus and Salmonella Enteritidis. The signal intensities of 3 -methyl-butanal from mixed cultures $\left(\times 10^{6}\right.$ for y-axis $)$ were reduced to only $10 \%$ of that from Staph. aureus pure culture $\left(\times 10^{7}\right.$ for $y$-axis; Figure 1$)$. The signal intensity of 3-methyl-butanoic acid from the other mixed cultures (with E. coli O157:H7, Strep. agalactiae, and S. flexneri) was higher than that of pure Staph. aureus culture, except for the mixed culture of Staph. aureus and Salmonella Enteritidis.

\section{Detectable Growth Level of Staph. aureus in Pasteurized and Raw Milks}

The correlations between 3-methyl-butanal and bacterial counts of Staph. aureus were not significant (Table 4), but those between 3-methyl-butanoic acid and Staph. aureus counts were significant $(P<0.01)$. Further, 3-methyl-butanal was detected in 2 blank pasteurized milk samples and 3 blank raw milk samples;

Table 4. Correlation coefficients between bacterial counts and signal intensities of the volatile compounds 3-methyl-butanal and 3-methylbutanoic acid produced from Staphylococcus aureus cultures in pasteurized milks and raw milks

\begin{tabular}{lcc}
\hline Milk sample & 3-Methyl-butanal & 3-Methyl-butanoic acid \\
\hline Pasteurized milk 1 & 0.367 & $0.920^{* *}$ \\
Pasteurized milk 2 & 0.266 & $0.928^{* *}$ \\
Pasteurized milk 3 & 0.382 & $0.887^{* *}$ \\
Raw milk 1 & -1 & $0.810^{* *}$ \\
Raw milk 2 & - & $0.886^{* *}$ \\
Raw milk 3 & - & $0.671^{*}$
\end{tabular}

${ }^{1}$ No increase in 3-methyl-butanal detected during culture.

${ }^{*} P<0.05 ;{ }^{* *} P<0.01$ therefore, the increase in 3-methyl-butanal signal was suitable for judging growth of Staph. aureus. The elevated 3-methyl-butanal signal in pasteurized milk was observed as Staph. aureus reached about $10^{6} \mathrm{cfu} / \mathrm{mL}$, whereas we did not detect any increase 3-methyl-butanal signal during the cultivation process in 3 raw milk samples (Table 5). Interestingly, 3-methyl-butanoic acid was not detected in 3 blank pasteurized milk or 3 blank raw milk samples. At the same time, 3-methyl-butanoic acid could be detected in pasteurized milk as Staph. aureus reached $10^{6}$ to $10^{7} \mathrm{cfu} / \mathrm{mL}$, and in raw milk as Staph. aureus reached $10^{5}$ to $10^{6} \mathrm{cfu} / \mathrm{mL}$ (Table 6).

\section{DISCUSSION}

3-Methyl-butanal, as a branched-chain volatile aldehyde, has been reported to be a key flavor compound, and can be produced from Staphylococcus xylosus (de Vos Petersen et al., 2004), Proteus vulgaris, Psychrobacter sp. (Deetae et al., 2007), and lactic acid bacteria (Afzal et al., 2017). It is well known that 3 -methyl-butanal is a transitory compound, which is usually biosynthesized from leucine catabolism using $\alpha$-ketoacid decarboxylase enzyme or $\alpha$-ketoacid dehydrogenase enzyme complex, and immediately oxidized into 3-methyl-butanoic acid (Beck et al., 2002; Afzal et al., 2013). In this study of Staph. aureus in milk, the 3-methyl-butanal signal increased beginning in the early exponential growth phase, reached a maximum value, and then decreased in the exponential and stationary growth phases; 3-methyl-butanoic acid could

Table 5. Growth of Staphylococcus aureus corresponding to the increase in 3-methyl-butanal signal

\begin{tabular}{lcc}
\hline Sample & $\begin{array}{c}\text { Growth } \\
(\mathrm{cfu} / \mathrm{mL})\end{array}$ & $\begin{array}{c}\text { Increase in 3-methyl- } \\
\text { butanal }(\text { counts } \times \mathrm{s})\end{array}$ \\
\hline Pasteurized milk 1 & $1.38 \times 10^{6}$ & $2.44 \times 10^{5}$ \\
Pasteurized milk 2 & $3.75 \times 10^{6}$ & $1.52 \times 10^{6}$ \\
Pasteurized milk 3 & $2.59 \times 10^{6}$ & $1.87 \times 10^{6}$ \\
Raw milk 1 & -1 & - \\
Raw milk 2 & - & - \\
Raw milk 3 & - & - \\
\hline
\end{tabular}

${ }^{1}$ No increase in 3-methyl-butanal was detected during culture of 3 raw milk samples. 
Table 6. Growth of Staphylococcus aureus corresponding to detectable signal intensity of 3-methyl-butanoic acid

\begin{tabular}{lcc}
\hline Sample & $\begin{array}{c}\text { Growth } \\
(\mathrm{cfu} / \mathrm{mL})\end{array}$ & $\begin{array}{c}\text { Detectable 3-methyl- } \\
\text { butanoic acid (count } \times \mathrm{s})\end{array}$ \\
\hline Pasteurized milk 1 & $3.97 \times 10^{6}$ & $7.93 \times 10^{7}$ \\
Pasteurized milk 2 & $4.65 \times 10^{7}$ & $3.12 \times 10^{7}$ \\
Pasteurized milk 3 & $3.09 \times 10^{7}$ & $3.36 \times 10^{7}$ \\
Raw milk 1 & $2.30 \times 10^{5}$ & $9.73 \times 10^{6}$ \\
Raw milk 2 & $1.54 \times 10^{6}$ & $1.32 \times 10^{7}$ \\
Raw milk 3 & $6.78 \times 10^{5}$ & $1.04 \times 10^{7}$ \\
\hline
\end{tabular}

be detected in the later exponential growth phase and increased steadily in the stationary growth phase. The low amounts of 3-methyl-butanal and the high amounts of 3-methyl-butanoic acid during the later growth period of Staph. aureus in milk were observed clearly in the current study, demonstrating that 3-methyl-butanal is a transient metabolite that would rapidly disappear from culture medium after production, leading to nonsignificant correlations between 3-methyl-butanal intensities and bacterial counts of Staph. aureus in most cases. However, 3-methyl-butanoic acid is a stable product in the metabolism of Staph. aureus, resulting in significant correlations between 3-methyl-butanoic acid intensities and bacterial counts of Staph. aureus.

Multiple bacteria occur simultaneously in real milk samples, so mixed cultures of Staph. aureus and other pathogens more closely mimic the actual situation. In the present study, we made binary mixed cultures of Staph. aureus and other pathogens. Production of 3-methyl-butanal generally decreased in all mixed cultures compared with Staph. aureus pure culture; however, the level of 3-methyl-butanoic acid was higher in mixed cultures than in Staph. aureus pure culture except for the coculture with Salmonella Enteritidis. Extracellular oxidation-reduction potential is an environmental factor that affects bacterial metabolic fluxes (Deetae et al., 2011; Matsuoka and Kurata, 2017). Kieronczyk et al. (2006) reported that oxidative conditions favor the production of aldehydes by amino acid catabolism, such as conversion of leucine to 3-methyl-butanal, and reducing conditions stimulate the production of carboxylic acids (e.g., 3-methyl-butanoic acid). Therefore, the decreased production of 3-methyl-butanal and increased production of 3-methyl-butanoic acid in the current study might be caused by the weaker oxidation state in mixed cultures than in pure culture. In this study, the release of 3-methyl-butanoic acid was suppressed for the combination of Staph. aureus with Salmonella Enteritidis. Growth inhibition of Staph. aureus by Salmonella Enteritidis was not observed during the logarithmic growth phase (Figure 2); rather, the maximum cell counts in the mixed culture of Staph. aureus and Salmonella Enteritidis were lower than in the pure culture of Staph. aureus during the stationary growth phase. Therefore, the decrease of 3-methyl-butanoic acid in the mixed culture of Staph. aureus and Salmonella Enteritidis might be caused by decomposition of Salmonella Enteritidis. Mpatswenumugabo et al. (2017) and Mekonnen et al. (2017) demonstrated that Staph. aureus and CNS were the frequently isolated mastitis pathogens from raw milk. A mixed culture of Staph. aureus with other CNS was not used in this study; however, the specificity of 3-methyl-butanoic acid for Staph. aureus might be supported by other research. For example, Hettinga et al. $(2008,2009 b)$ noted that 3 -methyl-butanal was produced by Staph. aureus and CNS, respectively, whereas 3-methyl-butyrate was only detectable in Staph. aureus. In the future, we will focus on the effects of CNS on volatiles of Staph. aureus through the mixed culture experiment and explore the different influencing factors.

In the present study, total bacterial counts were $1 \times$ $10^{6}$ to $3 \times 10^{6} \mathrm{cfu} / \mathrm{mL}$ for raw milk from dairy herds and $5 \times 10^{3}$ to $9 \times 10^{3} \mathrm{cfu} / \mathrm{mL}$ for pasteurized milk from supermarkets. Under this complex microbial flora, we could observe the growth of Staph. aureus and its production of volatiles. 3-Methyl-butanoic acid was detected in both pasteurized milk with $10^{6}$ to $10^{7} \mathrm{cfu} /$ $\mathrm{mL}$ of Staph. aureus and raw milk with $10^{5}$ to $10^{6} \mathrm{cfu} /$ $\mathrm{mL}$ of Staph. aureus. Similarly, Hettinga et al. (2009b) revealed that important volatile metabolites were released and accumulated to a detectable level after $8 \mathrm{~h}$ of incubation when the number of Staph. aureus in milk reached approximately $10^{7} \mathrm{cfu} / \mathrm{mL}$. In TSB culture of Staph. aureus, 3-methyl-butanoic acid was significantly released at a cell count of $5 \times 10^{7} \mathrm{cfu} / \mathrm{mL}$ (Filipiak et al., 2012). The studies confirmed that the concentration of volatile compounds increased and could be detected when the count of Staph. aureus reached a threshold value, similar to reports for other bacteria (Mayr et al., 2003; Ragaert et al., 2006; Silcock et al., 2014). On the other hand, milk and its products have been associated with staphylococcal food poisoning (Johler et al., 2015; Vitale et al., 2015; Jans et al., 2017), which is caused by consumption of food contaminated with enterotoxins produced by Staph. aureus. Generally, staphylococcal food poisoning is confirmed either by the recovery of at least $10^{5}$ Staph. aureus per gram or milliliter of food remnants or by the detection of staphylococcal enterotoxins (Hennekinne et al., 2012). The dose of enterotoxins reaches a certain level when the Staph. aureus population in contaminated food exceeds $10^{5} \mathrm{cfu} / \mathrm{g}$ or $\mathrm{cfu} / \mathrm{mL}$, and this toxin level could produce symptoms of staphylococcal intoxication (Necidová et al., 2012). In the present study, we detected 3-methyl-butanoic acid when Staph. aureus counts in milk reached $10^{5}$ to $10^{7} \mathrm{cfu} / \mathrm{mL}$, which suggested that the detectable level 
of 3-methyl-butanoic acid could be a marker for milk contaminated with Staph. aureus being hazardous to consumers. To our knowledge, no studies have focused on the relationship between the release of volatile metabolites and production of enterotoxins from Staph. aureus to date. Our future studies will illustrate the relationship between these 2 aspects.

\section{CONCLUSIONS}

3-Methyl-butanoic acid was a stable end product and its production correlated well with the growth of Staph. aureus at different temperatures and in different mixtures with other pathogens (except Salmonella Enteritidis) in sterile milk. 3-Methyl-butanal was a transient metabolite and its production was not significantly correlated with growth of Staph. aureus in most cases. In pasteurized and raw milks, production of 3-methly-butanoic acid was correlated significantly with the growth of Staph. aureus, and the volatile compound could be detected with Staph. aureus populations of $10^{6}$ to $10^{7} \mathrm{cfu} / \mathrm{mL}$ (pasteurized milk) and $10^{5}$ to $10^{6}$ $\mathrm{cfu} / \mathrm{mL}$ (raw milk). The corresponding correlations for 3 -methyl-butanal were not significant. The production characteristics of volatiles and their correlation with growth of Staph. aureus in milk points to a method for rapid and nondestructive detection by odor analysis for the milk industry.

\section{ACKNOWLEDGMENTS}

This work was jointly supported by the National Key Research and Development Program of China (2018YFD0500500, Beijing); the National Natural Science Foundation of China (31371781, Beijing); the Basic Applied Research Program of Sichuan Province (2014JY0253, Chengdu); and the Fundamental Research Funds for the Central Universities, Southwest University for Nationalities (2018NZD14, Chengdu). All authors declare that they have no conflict of interest. None of the authors has a financial or personal relationship with other individuals or organizations that could inappropriately influence or bias the contents of this paper.

\section{REFERENCES}

Afzal, M. I., C. C. Ariceaga, K. A. Boulahya, M. Jacquot, S. Delaunay, and C. Cailliez-Grimal. 2017. Biosynthesis and role of 3-methylbutanal in cheese by lactic acid bacteria: Major metabolic pathways, enzymes involved, and strategies for control. Crit. Rev. Food Sci. Nutr. 57:399-406.

Afzal, M. I., K. A. Boulahya, C. Paris, S. Delaunay, and C. Cailliez-Grimal. 2013. Effect of oxygen on the biosynthesis of flavor compound 3-methylbutanal from leucine catabolism during batch culture in Carnobacterium maltaromaticum LMA 28. J. Dairy Sci. 96:352-359.

Akindolire, M. A., O. O. Babalola, and C. N. Ateba. 2015. Detection of antibiotic resistant Staphylococcus aureus from milk: A public health implication. Int. J. Environ. Res. Public Health 12:1025410275 .

Beck, H. C., A. M. Hansen, and F. R. Lauritsen. 2002. Metabolite production and kinetics of branched-chain aldehyde oxidation in Staphylococcus xylosus. Enzyme Microb. Technol. 31:94-101.

Bi, Y., Y. J. Wang, Y. Qin, R. Guix Vallverdú, J. Maldonado García, W. Sun, S. Li, and Z. Cao. 2016. Prevalence of bovine mastitis pathogens in bulk tank milk in China. PLoS One 11:e0155621.

Bos, L. D., P. J. Sterk, and M. J. Schultz. 2013. Volatile metabolites of pathogens: A systematic review. PLoS Pathog. 9:e1003311.

Chen, J., J. Tang, H. Shi, C. Tang, and R. Zhang. 2017. Characteristics of volatile organic compounds produced from five pathogenic bacteria by headspace-solid phase micro-extraction/gas chromatography-mass spectrometry. J. Basic Microbiol. 57:228-237.

da Costa, L. B., P. J. Rajala-Schultz, and G. M. Schuenemann. 2016. Management practices associated with presence of Staphylococcus aureus in bulk tank milk from Ohio dairy herds. J. Dairy Sci. 99:1364-1373

de Vos Petersen, C., H. C. Beck, and F. R. Lauritsen. 2004. On-line monitoring of important organoleptic methyl-branched aldehydes during batch fermentation of starter culture Staphylococcus xylosus reveal new insight into their production in a model fermentation. Biotechnol. Bioeng. 85:298-305.

Deetae, P., P. Bonnarme, H. E. Spinnler, and S. Helinck. 2007. Production of volatile aroma compounds by bacterial strains isolated from different surface-ripened French cheeses. Appl. Microbiol. Biotechnol. 76:1161-1171.

Deetae, P., A. Sainteve, H. E. Spinnler, and S. Helinck. 2011. Critical effect of oxygen on aroma compound production by Proteus vulgaris. Food Chem. 126:134-139.

Filipiak, W., A. Sponring, M. M. Baur, A. Filipiak, C. Ager, H. Wiesenhofer, M. Nagl, J. Troppmair, and A. Amann. 2012. Molecular analysis of volatile metabolites released specifically by Staphylococcus aureus and Pseudomonas aeruginosa. BMC Microbiol. $12: 113-129$.

Gücükoğlu, A., T. O. Kevenk, T. Uyanik, O. Cadirci, G. Terzi, and M. Alisarli. 2012. Detection of enterotoxigenic Staphylococcus aureus in raw milk and dairy products by multiplex PCR. J. Food Sci 77:M620-M623.

Hennekinne, J. A., M. L. De Buyser, and S. Dragacci. 2012. Staphylococcus aureus and its food poisoning toxins: Characterization and outbreak investigation. FEMS Microbiol. Rev. 36:815-836.

Hettinga, K. A., H. J. van Valenberg, T. J. Lam, and A. C. van Hooijdonk. 2008. Detection of mastitis pathogens by analysis of volatile bacterial metabolites. J. Dairy Sci. 91:3834-3839.

Hettinga, K. A., H. J. van Valenberg, T. J. Lam, and A. C. van Hooijdonk. 2009a. The origin of the volatile metabolites found in mastitis milk. Vet. Microbiol. 137:384-387.

Hettinga, K. A., H. J. van Valenberg, T. J. Lam, and A. C. van Hooijdonk. 2009b. The influence of incubation on the formation of volatile bacterial metabolites in mastitis milk. J. Dairy Sci 92:4901-4905.

Jans, C., A. Merz, S. Johler, M. Younan, S. A. Tanner, D. W. Kaindi J. Wangoh, B. Bonfoh, L. Meile, and T. Tasara. 2017. East and West African milk products are reservoirs for human and livestockassociated Staphylococcus aureus. Food Microbiol. 65:64-73.

Johler, S., D. Weder, C. Bridy, M. C. Huguenin, L. Robert, J. Hummerjohann, and R. Stephan. 2015. Outbreak of staphylococcal food poisoning among children and staff at a Swiss boarding school due to soft cheese made from raw milk. J. Dairy Sci. 98:2944-2948.

Kieronczyk, A., R. Cachon, G. Feron, and M. Yvon. 2006. Addition of oxidizing or reducing agents to the reaction medium influences amino acid conversion to aroma compounds by Lactococcus lactis. J. Appl. Microbiol. 101:1114-1122.

Matsuoka, Y., and H. Kurata. 2017. Modeling and simulation of the redox regulation of the metabolism in Escherichia coli at differ- 
ent oxygen concentrations. Biotechnol. Biofuels 10:183. https:// doi.org/10.1186/s13068-017-0867-0.

Mayr, D., R. Margesin, E. Klingsbichel, E. Hartungen, D. Jenewein, F. Schinner, and T. D. Märk. 2003. Rapid detection of meat spoilage by measuring volatile organic compounds by using proton transfer reaction mass spectrometry. Appl. Environ. Microbiol. 69:46974705 .

Mekonnen, S. A., G. Koop, S. T. Melkie, C. D. Getahun, H. Hogeveen, and T. J. G. M. Lam. 2017. Prevalence of subclinical mastitis and associated risk factors at cow and herd level in dairy farms in North-West Ethiopia. Prev. Vet. Med. 145:23-31.

Mirzaei, H., A. Tofighi, H. K. Sarabi, and M. Farajli. 2011. Prevalence of methicillin-resistant Staphylococcus aureus in raw milk and dairy products in Sarab by culture and PCR techniques. J. Anim. Vet. Adv. 23:3107-3111.

Mpatswenumugabo, J. P., L. C. Bebora, G. C. Gitao, V. A. Mobegi, B. Iraguha, O. Kamana, and B. Shumbusho. 2017. Prevalence of subclinical mastitis and distribution of pathogens in dairy farms of Rubavu and Nyabihu districts, Rwanda. J. Vet. Med. 2017:8456713. https://doi.org/10.1155/2017/8456713.

Necidová, L., B. Janštová, and R. Karpišková. 2012. Dynamics of staphylococcal enterotoxin production in model experiments simulating the fresh cheese environment. Acta Vet. Brno 81:391-396.
Ragaert, P., F. Devlieghere, E. Devuyst, J. Dewulf, H. Van Langenhove, and J. Debevere. 2006. Volatile metabolite production of spoilage micro-organisms on a mixed-lettuce agar during storage at 7 degrees $\mathrm{C}$ in air and low oxygen atmosphere. Int. J. Food Microbiol. 112:162-170.

Silcock, P., M. Alothman, E. Zardin, S. Heenan, C. Siefarth, P. J Bremer, and J. Beauchamp. 2014. Microbially induced changes in the volatile constituents of fresh chilled pasteurized milk during storage. Food Packag. Shelf Life 2:81-90.

Tait, E., J. D. Perry, S. P. Stanforth, and J. R. Dean. 2014. Identification of volatile organic compounds produced by bacteria using HS-SPME-GC-MS. J. Chromatogr. Sci. 52:363-373.

Vahedi, M., M. Nasrolahei, M. Sharif, and A. M. Mirabi. 2013. Bacteriological study of raw and unexpired pasteurized cow's milk collected at the dairy farms and super markets in Sari city in 2011. J. Prev. Med. Hyg. 54:120-123.

Vitale, M., M. L. Scatassa, C. Cardamone, G. Oliveri, C. Piraino, R. Alduina, and C. Napoli. 2015. Staphylococcal food poisoning case and molecular analysis of toxin genes in Staphylococcus aureus strains isolated from food in Sicily, Italy. Foodborne Pathog. Dis. $12: 21-23$. 